\title{
CHANGES IN ACTIVITIES OF POLYPHENOL OXIDASE, ASCORBATE, PEROXIDASE, HYDROPEROXIDE AND LIPID LEVELS DURING DESICCATION OF IRVINGIA GABONENSIS (VARIETY EXCELSA) SEEDS.
}

\author{
P. J. NYA, D. N. OMOKARO and A. E. NKANG
}

(Received 3 September 2002; Revision accepted 6 Jamury 2003)

\begin{abstract}
Activities of peroxidase (POD), Polyphenol oxidase (PPO), hydroperoxide and lipid contents were investigated during desiccation of cotyledonary tissues of Invingia gabonensis at anbient temperature $\left(26^{\circ} \mathrm{C}-30^{\circ} \mathrm{C}\right), 35^{\circ} \mathrm{C}$ and $20^{\circ} \mathrm{C}$. Activities of $\mathrm{POD}$ and $\mathrm{PPO}$ increased initially but declined in the latter desiccation period. However, loss of enzymic activity (POD and PPO) occurred generally at moisture content less than 20\%. The hydroperoxide and lipid leveis increased during desiccation irrespective of stage of seed development. Results suggest that seeds show peroxidation with drying, that is spontaneous oxidation of unsaturated fatly acids. Lipid peroxidalion was very pronounced in Irvingia gabonensis seeds indicating the need for rapid ding at relatively high temperature in order to maintain seed quality.
\end{abstract}

Key Words: POD: Peroxidase, PPO. Polyphenol oxidase, RMC; Relative Moisture Content; Irvingia gabonensis

\section{INTRODUCTION}

Bush mango (Irvingia gabonensis) is found growing in the forest and rarely culitvated Cultivation is usually limited to areas where indigenous agricultural system embraces the cultivation of trees (Donna et. al, 1994 and Okafor, 1981). The uses of bush mango (or ogbono) are vast. Its seeds are used in soups as thickeners. Their cotyledons can be dried, ground and processed into a "cake" which is further smoked, stored and eaten readily with yam or plantain. In whatever form it is prepared "Ogbono" has a high nutritive and dietary value in terms of fats $(72 \%)$ and protein ( $9 \%$ ) (Okafor and Okolo, 1974; Ejiofor, 1994). The seedlings which could be used for farm planting are not easy to obtain because of the apparent domancy of seed lols resulting in poor germination result (Omokaro et al, 1999)

There is therefore, the necessity to carry out procedures for the development of techniques of seed quality assessment for the selection of superior strains for commercial purposes.

There are great differences among seed in their content of food res arves. The composition of seeds influences their moisture content and consequently their storage behaviour (Street and Opik, 1977; and Vaughan and Duke, 1984). In some seeds including many legumes, high levels of proteins together with a higher amount of starch and a little lipid are found (Corners, 1978 and Kahn, 1983).

Increase in moisture content results in increased seed deterioration. Most seeds are better stored using conventional methods at low moisture contents. Seed with. relatively high moisture contents up to $68.8 \%$ in fluted pumpkin. can germinate during storage (Ikediobi, 1985; Hailstones and Smiths, 1989).

Desiccation injury, loss of viability and membrane, enzyme or transport disruption may occur at low moisture content (Harrington, 1972; Smith and Adamson, 1989). For most saeds, drying below a certain moisture content induces loss of viability irrespective of the storage condition (Bass, 1979; and Barton, 1961). Seeds of many tropical trees are high in moisture content and cannot withstand intensive desiccation. These are recalcitrant seeds as opposed or orthodox seeds which can tolerate desiccation for low moisture contents (King and Robert, 1979).

Browning in most plant tissues is caused primarily by the activity of the enzyme polyphenol oxidase. The activity of polyphenol oxidase and the content of polyphenol are usually considered as the main factors contributing to the browning potential of tissues (Vaughan and Duke, 1984; Nkang and Chandler., 1986).

Knowledge of biochemical activities associated with moisture content, storage and desiccation of Irvingia gabonensis (Bush mango) is useful, as it will permit the assessment of seed

P. J. NYA, Department of Botany, University of Calabar, Calabar, Nigeria

D. N. OMOKARO, Department of Botany, University of Calabar, Calabar, Nigeria

A. E. NKANG, Department of Botany, University of Calabar, Calabar, Nigeria 
quality. In this study investigations have been carried out on the PPO, POD, lipids and hydroperoxide contents of Irvingia gabonensis during desiccation of mature and immature seeds.

\section{MATERIALS AND METHODS}

\section{Seed collection and desiccation}

Fresh fruits of Irvingia gabonensis were harvested in Nsan village in Akamkpa Local Government Area of Cross River State of Nigeria between the months of June and July 1998. Seeds of approximately the same size and physiological maturity were used in carrying out the experiments.

The selected seeds were spread on the laboratory bench at ambient temperature (approx. $28^{\circ} \mathrm{C}-30^{\circ} \mathrm{C}$ ). Some seeds were dried in an incubator at $20^{\circ} \mathrm{C}$ and $35^{\circ} \mathrm{C}$. Seeds were removed at daily intervals for the determination of moisture content, lipid and hydroperoxide levels and enzymes activity. The moisture content was determined on a fresh weight basis after ovendrying at $80^{\circ} \mathrm{C}$ for 72 hours.
Extraction and Assay of polyphenol oxidase and ascorbate peroxidase

1. Enzyme Extraction: Enzyme extraction and assay were done in duplicate. One gram fresh weight of cotyledonary tissues from each desiccation treatment was ground into paste using a pestle and mortar in $20 \mathrm{ml}$ of extraction buffer $\left(\mathrm{pH}\right.$ at $\left.5^{\circ} \mathrm{C}\right)$. The homogenate or mixture was centrifuged at $10,000 \mathrm{rpm}$ for 3 minutes.

The supernatant fraction was stored on ice and used as crude enzyme source.

2.

\section{Enzyme Assay \\ (a) Polyphenol Oxidase}

To $2 \mathrm{mls}$ of assay buffer (mixed $20 \mathrm{Mm}$ potassium phosphate buffer, potassium salts, $\mathrm{pH} 7.0$ ) at $30^{\circ} \mathrm{C}$ was added to $500 \mathrm{ml}$ of enzyme preparation and $0.5 \mathrm{mis}$ of dihydroxyphenylalanine (10mM DOPA) for one minute. $(50 \mu l$ of $50 \%$ stock $\mathrm{H}_{2} \mathrm{O}_{2}$ and $5 \mathrm{ml}$ of distilled $\mathrm{H}_{2} \mathrm{O}$ )

TABLE 1: CHANGES IN POD AND PPO ACTIVITIES IN MATURE FRUITS OF lrvingia gabonensis DESICCATION INTACT $\triangle T 28-300 \mathrm{C}(\mathrm{MEAN} \pm \mathrm{S} . \mathrm{E})$

\begin{tabular}{|c|c|c|c|c|}
\hline \multirow{2}{*}{$\frac{\text { Desiccation }}{\text { (Days) }}$} & \multicolumn{2}{|c|}{ Peroxidase } & \multicolumn{2}{|c|}{ Polyphenol Oxidase } \\
\hline & Absorbance & Activity $(\mathrm{M} / \mathrm{L})$ & Absorbance & Activity (M/L) \\
\hline On collection & $1.11 \pm 0.00$ & $2040.76 \pm 2.01$ & $1.56 \pm 0.00$ & $6.640+0.84$ \\
\hline 3 & $1.32 \pm 0.10$ & $2426.86 \pm 4.00$ & $1.99 \pm 0.01$ & $8.471 \pm 0.63$ \\
\hline 7 & $1.33 \pm 0.00$ & $2445.24 \pm 5.01$ & $1.99 \mathrm{t} 0.01$ & $8.471 \pm 0.71$ \\
\hline 12 & $1.41 \pm 0.20$ & $2592.32 \pm 4.09$ & $1.64 \pm 0.00$ & $6.981 \pm 0.16$ \\
\hline
\end{tabular}

The paraneters are reported as mean \pm Standard Error of five readings.

TABLE 2: CHANGES IN ACTIVITIES OF POD AND PPO IN IMMATURE FRIUTS DESICCATED AT 28-30 C (MEAN t S.E)

Desiccation Time

Peroxidase

Polyphenol Oxidase

\begin{tabular}{|l|l|l|l|l|}
\hline (Days) & Absorbance & Activity (M/C) & Absorbance & Activity (M/C) \\
\hline On Collection & $0.38 \pm 0.00$ & $269.04: 2.20$ & $0.96 \pm 0.01$ & $4.087 \pm 0.60$ \\
\hline 3 & $1.37 \pm 0.01$ & $2518.76 \pm 3.00$ & $1.00 \pm 0.04$ & $8.471+1.30$ \\
\hline
\end{tabular}

The parameters are reported as mean \pm Standard Error of five readings 
TABIE 3: CHANGES IN ACTIVITIES OF POD AND PPO IN MATIIRI: FRUITS OF Irvinga gabonensis DURING DESICCATION AT $35^{\circ} \mathrm{C}(\mathrm{MEAN} \pm$ S.E)

Desiccation Time

RMC Peroxidase

Polyphenol Oxidase

\begin{tabular}{|l|l|l|l|l|l|}
\hline (Days) & $\%$ & Absorbance & Activity N/L & Absorbance & Activity (N/L) \\
\hline & & & & $\mathrm{E}$ & \\
\hline On collection & $40.0 \pm 0.00$ & $1.11 \pm 0.00$ & $2040.76 \pm 0.80$ & $1.56 \pm 0.00$ & $6.641 \pm 0.16$ \\
\hline 3 & $30.0 \pm 0.01$ & $1.30 \pm 0.01$ & $2390.08 \pm 1.10$ & $1.60 \pm 0.00$ & $6.811 \pm 0.92$ \\
\hline 7 & $20.0 \pm 1.12$ & $1.43 \pm 0.12$ & $2629.09 \pm 1.12$ & $1.97 \pm 0.00$ & $8.343 \pm 0.70$ \\
\hline 12 & $10.0 \pm 1.20$ & $1.00 \pm 0.60$ & $2334.92 \pm 2.10$ & $1.99 \pm 021$ & $8.471 \pm 0.08$ \\
\hline 15 & $10.0 \pm 0.0$ & $1.27 \pm 0.60$ & $2334.92+2.10$ & $1.99 \pm 0.21$ & $8.471 \pm 0.10$ \\
\hline 18 & $10.0 \pm 0.10$ & $1.98 \pm 0.16$ & $1801.75 \pm 3.12$ & $1.53 \pm 0.01$ & $6.513 \pm 0.60$ \\
\hline
\end{tabular}

The parameter are reported as mean \pm Standard Error of five readings

TABLE 4: CHANGES IN ACTIVITIES OF POD AND PPO IN MATURE FRUITS OF Irvingia gabonensis DURING DESICCATION AT $20^{\circ} \mathrm{C}$ (MEAN $I$ S.E)

\begin{tabular}{|l|l|l|l|l|l|}
\hline $\begin{array}{l}\text { Desiccation } \\
\text { Time }\end{array}$ & \multicolumn{4}{|c|}{ Peroxidase } & \multicolumn{2}{c|}{ Polyphenoloxidase } \\
\hline Days & RMC $\%$ & Absorbance & Activity (N/C) & Absorbance & Activity (N/L) \\
\hline On collection & $46.0 \pm 1.30$ & $1.11 \pm 0.00$ & $2040.76 \pm 0.71$ & $1.56 \pm 0.00$ & $6.641 \pm 0.60$ \\
\hline 3 & $38.4 \pm 0.97$ & $1.40 \pm 0.00$ & $2573.93 \pm 1.33$ & $1.55 \pm 0.00$ & $6.598 \pm 0.60$ \\
\hline 7 & & & & & \\
\hline 12 & $30.0 \pm 2.04$ & $141 \pm 0.00$ & $2592.32 \pm 3.01$ & $1.99 \pm 0.00$ & $8.471 \pm 0.84$ \\
\hline 13 & $30.0 \pm 2.04$ & $1.52 \pm 0.00$ & $2794.56 \pm 4.10$ & $1.99 \pm 0.00$ & $8.471 \pm 0.16$ \\
\hline & $20.0 \pm 2.01$ & $1.40 \pm 0.00$ & $2573.93 \pm 3.10$ & $1.99 \pm 0.00$ & $8.471 \pm 0.07$ \\
\hline
\end{tabular}

The parameters are reported as mean \pm Standard Error of five readings.

The mixture was incubated for one minute at $30^{\circ} \mathrm{C}$ and the absorbance measured colorimetically at $470 \mathrm{mM}$ against a blank of water. Activities of PPO are expressed as Mmole quinone product $\operatorname{Sec}^{-1} \mathrm{~L}^{-1}$ and calculated using an extinction coefficient of $1433 \mathrm{~m}-\mathrm{cm}^{-1}$ (Jimenez and Garcia-Carmora, 1995).

\section{Ascorbate Peroxidae}

To $3 \mathrm{ml}$ of assay buffer was added $200 \mu$ l of enzyme preparation. To this was added $100 \mu$ of substrate $(100 \mathrm{~mm}$ ascorbate). The reaction was started with the addition of $50 \mu \mathrm{H}$ of $\mathrm{H}_{2} \mathrm{O}_{2}$ preparation $\left(50 \mu \mathrm{l}\right.$ of $50 \%$ stock $\mathrm{H}_{2} \mathrm{O}_{2}$ in $5 \mathrm{~m} / \mathrm{s}$ of $\mathrm{H}_{2} \mathrm{O}_{2}$. The absorbance of the mixture after 60 seconds were measured colorimetrically at
430nM with water as blank. POD activity expressed as $\mathrm{Mmol}$ ascorbate product oxidized $\mathrm{Sec}^{-1}$ was calculated using an extinction coefficient of $6.391 \mathrm{~mol}^{-1} \mathrm{~cm}^{-1}$ for ascorbate (Putter, 1974).

\section{Extraction of Lipids}

Lipids were extracted as described by Hailstone and Smith, (1988). Lipids were extracted from $0.3 \mathrm{~g}$ dry weight of ground cotyldonary tissue in $20 \mathrm{mls}$ of a solvent system of petroleum ether and methanol (2: 1, VN) containing $0.006 \%$ of the antioxidant butylated hydroxytoluene. Lipids were determined graimetrically after extraction at $65^{\circ} \mathrm{C}$.

\section{Determination of Hydroperoxide}

Hydroperoxides were determined in the 
pid extracts. To $50 \mathrm{~m} /$ of $0.14 \mathrm{~m}$ ferrous chloride vas added $2 \mathrm{mls}$ of benzene and $1 \mathrm{ml}$ methanol ind shaken. $50 \mu \mathrm{l}$ OF $3 \mathrm{M}$ potassium thiocyanate. The absorbance of the resulting solution was read zolorimtrically at $505 \mathrm{~nm}$ against a blank of the eagents (Smith and Adamson, 1989).

\section{RESULT}

Activities of peroxidase (POD) increased yradually during desiccation of mature Irvingia yabonensis seeds at ambient temperature. Jolyphenol oxidase (PPO) activity increase similary but with activity decreasing at the end of he desiccation period (Table 1).

The relative moisture content in the seeds of Irvingia gabonensis decreased with time irrespective of the desiccation temperature and stage of maturity (Table 3 and 4 ). The seeds dried at $35^{\circ} \mathrm{C}$ lost moisture more rapidly than the others (Table 3 ).

In general, activities of $\mathrm{POD}$ and $\mathrm{PPO}$ increased initially but declined with prolonged desiccation in seeds kept at ambient temperature and $35^{\circ} \mathrm{C}$.
In seeds dried at $20^{\circ} \mathrm{C}$ PPO activity increased throughout the desiccation period. On the other hand, PPO activity increased initially but thereafter decreased slightly at the end of the desiccation treatment (Table 4).

Seeds of Irvingia gabonensis demonstrated a relatively high moisture content at harvest (Table 5 and 6 ). The seeds dried at $35^{\circ} \mathrm{C}$ lost moisture more rapidly to those dried at $20^{\circ} \mathrm{C}$, moisture content declined with desiccation in both cases. In general, lipid and hydroperoxide level appeared to increased gradually with time during desiccation at both temperatures (Table 5 and 6 ).

\section{DISCUSSION}

Activities of peroxidases have been implicated and associated with various physiological processes including germination, ripening, abscission and fruit development (Gasper et al, 1972; Asins ef al 1984). In this study, activities of peroxidase (POD) increased gradually during desiccation of mature Irvinga gabonensis seeds at ambient temperature. The

T"ABIE 5: ERFLCT OF DESICCATION IN Irvingia gabonensis SEEDS AT 20"C (MEAN \pm S.E)

\begin{tabular}{|c|c|c|c|}
\hline Desiccation Period Days & $\begin{array}{l}\text { Relative Moisture } \\
\text { Content }(\%)\end{array}$ & $\frac{\text { Lipid Content }}{\text { (Mg Lipid g-IDW) }}$ & $\begin{array}{l}\text { Hydroperxide } \\
\text { (Abs. } 505 \mathrm{~mm} \text { ) }\end{array}$ \\
\hline 0 & 39.110 .4 & $38.1 \pm 1.3$ & $0.35+0.5$ \\
\hline 3 & 38.410 .3 & $40.1 \pm 1.0$ & $0.47 \pm 0.1$ \\
\hline 5 & $30.0 \pm 1: 1$ & 42.411 .4 & $0.45 \pm 0.0$ \\
\hline i) & $30.0+1.2$ & $56.1 \pm 1.7$ & $0.50 \pm 0.6$ \\
\hline 12 & $20.0+0.3$ & $48.3 \pm 1.2$ & $0.50: 0.1$ \\
\hline 15 & $20.0+0.6$ & $50.5+1.3$ & $0.50 \pm 0.0$ \\
\hline
\end{tabular}

The parmeters are reported as mean ts Standard Error of five readins.

M13!1.6

IFFECT OF DESICCATION IN Irvingia gabonensis SEED AT $35^{\circ} \mathrm{C}$ (MEAN \pm S.E)

\begin{tabular}{|c|c|c|c|}
\hline Destication Period Days & $\begin{array}{l}\text { Rekative Moisture } \\
\text { Content }(\%)\end{array}$ & $\frac{\text { Lipid Content }}{\text { (Mglipid E-IDW) }}$ & $\begin{array}{l}\text { Hydroperoxide (Abs. } 505 \\
\mathrm{~mm} \text { ) }\end{array}$ \\
\hline 0 & 46.010 .06 & $38.1 \pm 0.42$ & $0.35 \pm 0.02$ \\
\hline 3 & 30.010 .94 & $40.8+0.71$ & $0.35+0.01$ \\
\hline 6 & $20.0 \pm 0.03$ & $42.4 \pm 0.54$ & $0.43 \pm 0.07$ \\
\hline 9 & $10.0+0.00$ & $41.0+0.61$ & $0.45 \pm 0.01$ \\
\hline 12 & 10.010 .20 & $56.1 \pm 0.10$ & $0.53 \div 0.03$ \\
\hline 15 & $10.0 \pm 0.30$ & $56.1+0.21$ & $0.53+0.00$ \\
\hline
\end{tabular}

The parameters are reported as mean ts Standard Lror of five readings. 
pattern of polyphenol oxidase (PPO) activity was similar to that of POD, increasing initially and thereafter declining with severe desiccation. This agrees with a suggestion (Harrington, 1972) that desiccation injury, loss of viability and membrane, enzyme or transport disruption may occur at low moisture.

The subsequent declines in the peroxidation activity occurred generally at moisture content less than $20 \%$ and may be associated with some level of deterioration (stress damage). This went to confirm what (King and Robert, 1979) reported, that seeds of many tropical trees are high in moisture and cannot withstand intensive desiccation. However, Irvingia gabonensis seeds exhibits recalcitrant viability characteristics.

The loss of enzymic activity with prolonged desiccation was apparent in all the treatments. This may be as result from the depletion of substrates of reduced transport or accessibility of substrates as a results of desiccation. This agrees with a suggestion (Bass, 1979) that increase endogenous hydrolytic activity might lead to distribution in metabolism which could result in enzyme inactivation. Increase activity of ascorbate peroxidase may be part of an endogenous mechanism that protect membrane and enzymes during desiccation.

Seeds of Irvingia gabonensis showed greatly increased hydroperoxide levels with desiccation. This suggests a change in the level of unsaturated fatty acids with desiccation. Lipid levels also increased with desiccation in Irvingia ganbonensis seeds. This agrees with what (Hailstone and Smiths, 1989; Smith and Adamson, 1989) suggested that spontaneous oxidation of unsaturated fatty acids in lipids produce highly reactive intermediates, hydroperoxides and secondary products. Also peroxidation of seed lipids during storage could lead to changes in the relative percentages of constituent fatty acids due to the preferential breakdown of unsaturated fatty acids. However,

seeds of Irvingia gabonensis seem to show peroxidation with drying. The quality of the final procluct may therefore guaranteed if the seeds are dried at a higher temperature (about $60^{\circ} \mathrm{C}$ ).

\section{ACKNOWLEDGEMENT}

Dr. Omokaro and Mr. Paul Nya acknowiedge with thanks the support of the University of Calabar Senate Research Grant for the on-going studies in the physiology and biochemistry of Irringia gabonensis seeds.
REFERNCES

Asins, M. i., Benito, C. and Perezde la Vaga, 1983. A Comparative study of the changes of peroxidase patterns during wheat, rice, triticale germination Canadian Journal of Botary. 61:3393 -3398 .

Barton, L. V., 1961. Seed preservation and longevity. Interscience publishers Inc. New York, pp320.

Bass, I.N., 1979. Physiological and other aspects of seed preservation In: The plant seed development, Preservation and (jermination. (Irwin Rubenstein, Ronald C. Phillips, Charles E.. Green and Gengenbach, B.(3. eds,). Academic Press, l.ondon, $p$ p 145-165.

Corncrs, L. J. II., 1976. The secods of dicotyledons Vol. 1. Cambridge University Press, London, pp. 113-124.

Doma, M. A., Ogar, A. F. and Otu, I. I., 1994. ^ user survey on livingia gahonensis in Cross River State-Nigeria. Local Storage methods of Bush Mango. A paper presented at the pregermplasm collection meeting on lrvingia gabonensis organized by ICRAFT, Nairobi, Kenya held at 1.'T.T.A., Ibadan, Nigeria, 10-14 May, 1994, pp. 18.

Fiofor, M. A. N., 1994. Nutritional values (and utilities) of "Ogbono", Irvingia gabonesis var. excelsa. A paper presented at the Germplasm collection meeting at IITA, sponsored by Intemational Centre for Research in Agroforestry (ICRAF), 10- 11 May, 1094. ITA, Ibadan, Nigeria, Pp 1-7.

Gasper, T. H., Penel, G., Thorpe, T. and Gripin, H., 1982. Peroxidase: 1970 1980. A survey of their biochemical and physiological role in higher plants University of Geneva.

Ilailstones, M. A. and Sinith, M. T., 1988. Lipid peroxidation in relation to declining Vigor of secds of Soya (Glycine max) and Cabbage (Brassica oleracea). Jounal of Plant physiology, 133: 452 453.

Harrington, J. F. and Roberts, E. H. (1972). Seed storage and longevity. In: Seed Biology vol. 3. (T. T. Kozlowiski). New York, pp. 145-245.

Ikediobi, C. O., 1985. Biochemistry and Physiology of yam storage. In Advances in yam Research. Osuiji, G. ed. Biochemistry Socicty of Nigeria, Anambra State University of Science and Technology, Enugu,

limenaz, $M$. and Garcia-Carmona, F., 1995. pH - induced Hysteris of latent Broad Bean polyphenol oxidase: Phytochemistry 40: pp 373-376.

Whan, A. A., 1993. The Plyssiological and Biochemistry of 
seed development, Dormancy and Germination. Elsevier Bio-Medical Press, Amsterdam, New York, pp. $185-371$

King, M. N. and Robert, E. II.. 1979, The storage of recalcitrant seeds: Achievement and possible approaches. IBPCIER. Fisecutive Secretariat Rome.

Nkang, $\wedge$. and Chandler, $C .$, 1986. Changes during embryogenesis in rain forest seeds with orthodox and recalcitrant viability characteristics. Joumal of Plant Physiology. 126: 243-256.

Okafor, J. C. and Okolo, H. C., 1974. Potentialities of some indigenous fruits trees of Nigeria. Proc. Fifth Annual Conference Forestry. Association of Nigeria. p. 15.

Okafor, I. C., 1981. Woody Plants of Nutritional Importance in Traditional farming System of the Nigerian Humid Tropics, Ph. D. Thesis, University of Ibalan (unpublished). Pp. 12-20.
Omokaro, D. N., Nkang, A and Nya, P. J., 1999. Effects of Desiccation and Subsequent Dehydration on the germination of Irvingia gabonensis Var. excelsa seeds. Seed Science and Technology. 27: 877-884.

Putter, J., 1974. Peroxidase: In: Methods of Enzymatic Analysis (ed. H. U. Bergmey). Verlay Chemic Meinlreim. pp. 685-690.

Smith, M. T. and Adamson, J. H. A., 1989. Volatile lipid peroxidation breakdown products and viabulity in seeds of lettuce (Lactrua Sative L.) south Africa Journal of Science. 85: 63-64.

Strect, II. E. and Opik, H., 1977. The physiology flowering plants. $2^{\text {mit }}$ Edition, English Language Book Society (ELBS) and Edward Arnold (Publishers) Ltd., London, pp. 5-28.

Vaughan, K. C. and Duke, S. O.. 1984. Functions of Polyphenol oxidase in higher plants. Plant Physiology. 60: 106-112. 